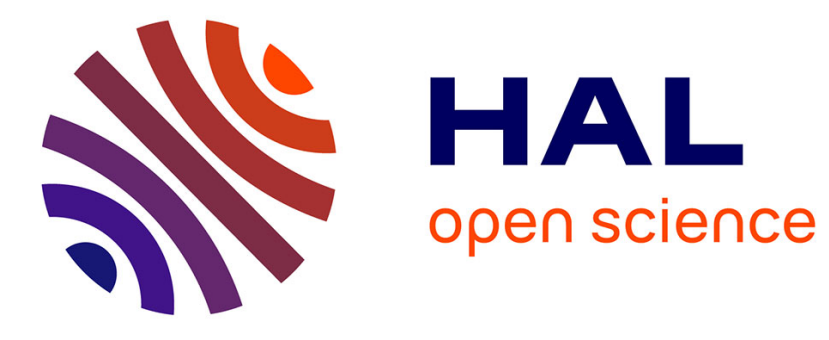

\title{
Modeling the PV generator behavior submit to the open-circuit and the short-circuit faults
}

Wail Rezgui, Nadia Kinza Mouss, Leïla-Hayet Mouss, Mohamed Djamel Mouss, Yassine Amirat, Mohamed Benbouzid

\section{To cite this version:}

Wail Rezgui, Nadia Kinza Mouss, Leïla-Hayet Mouss, Mohamed Djamel Mouss, Yassine Amirat, et al. Modeling the PV generator behavior submit to the open-circuit and the short-circuit faults. 2014 IEEE EFEA, Nov 2014, Paris, France. pp.1-6, 10.1109/EFEA.2014.7059978 . hal-01154199

\author{
HAL Id: hal-01154199 \\ https://hal.science/hal-01154199
}

Submitted on 21 May 2015

HAL is a multi-disciplinary open access archive for the deposit and dissemination of scientific research documents, whether they are published or not. The documents may come from teaching and research institutions in France or abroad, or from public or private research centers.
L'archive ouverte pluridisciplinaire HAL, est destinée au dépôt et à la diffusion de documents scientifiques de niveau recherche, publiés ou non, émanant des établissements d'enseignement et de recherche français ou étrangers, des laboratoires publics ou privés. 


\title{
Modeling the PV Generator Behavior Submit to the Open-Circuit and the Short- Circuit Faults
}

\author{
Wail Rezgui ${ }^{1}$, Nadia Kinza Mouss ${ }^{1}$, Leïla-Hayet Mouss ${ }^{1}$, \\ Mohamed Djamel Mouss ${ }^{1}$, Yassine Amirat ${ }^{2}$ and Mohamed Benbouzid ${ }^{3}$ \\ ${ }^{1}$ LAP-lab, University of Batna, Batna, Algeria \\ Email: r-wail@hotmail.fr, kinzmouss@yahoo.fr, hayet_mouss@yahoo.fr, d_mouss@yahoo.fr \\ ${ }^{2}$ ISEN Brest, EA 4324 LBMS, Brest, France \\ Email: Yassine.Amirat@,isen.fr \\ ${ }^{3}$ University of Brest, EA 4325 LBMS, Brest, France \\ Email: Mohamed.Benbouzid@univ-brest.fr
}

\begin{abstract}
In this paper, we proposed a new mathematical model of a faulty photovoltaic generator operation. It presents its behavior, when it's subjected to the open-circuit and the short-circuit faults at its basic components as: cells, bypass diodes and blocking diodes.

Such kind of modeling will allow developing fault detection and diagnosis methods. Indeed, the proposed model will be used to set normal and fault operation conditions database, which will facilitate learning and classifications phases.
\end{abstract}

Index Terms - Photovoltaic Generator; I-V Characteristic; Modeling; Simulation; Short-Circuit and Open-Circuit Faults.

\section{NOMENCLATURE}

$\begin{array}{ll}P V & =\text { Photovoltaic Generator. } \\ p h i & =\text { Photocurrent. } \\ V_{\text {Cell_open-circuit }} & =\text { Open-Circuit Voltage of Cell. } \\ I_{\text {Cell_Short-circuit }} & =\text { Short-Circuit Current of Cell. } \\ I_{0} & =\text { Reverse Saturation Current of the Diode. } \\ R_{S} & =\text { Cell Series Resistance. } \\ R_{S H} & =\text { Cell Shunt Resistance. } \\ n c: n c g / n c p & =\text { Cell Number: Good / Defective. } \\ n g: n g g / n g p & =\text { Group Number: Good / Defective. } \\ n m: n m g / n m p & =\text { Module Number: Good / Defective. } \\ n s: n s g / n s p & =\text { String Number: Good / Defective. } \\ n f g / n f p & =\text { Good / Defective Generator. } \\ N_{\text {Cells }} & =\text { Cells Number in each Group. } \\ N_{\text {Groups }} & =\text { Groups Number in each Module. } \\ N_{\text {Modules }} & =\text { Modules Number in each String. } \\ N_{\text {Strings }} & =\text { Strings Number in the Generator. } \\ V / I & =\text { Voltage / Current. } \\ P & =\text { Power. } \\ V_{\text {Cell_imposed }} & =\text { Voltage Imposed. } \\ D T V & =\text { Diode Thermal Voltage. } \\ a & =\text { Diode Ideality Factor. }\end{array}$

\section{INTRODUCTION}

The PV system productivity depends largely on two factors [4-5]: its performance, which is generally in the function of the weather conditions, such as solar radiation, temperature and wind speed. And secondly, its availability presents the continuity of the energy production service.

The existence of defects can reduce the productivity of the generator system, like the open-circuit and the short- circuit faults [6-7]. Modeling these latter can predict its influence [1-2], then deciding to make the diagnosis or the prognosis of the faulty components, before its unavailability [17-19].

In this context, the paper objective is the development of a new mathematical model, for the faulty operation of the PV generator, particularly when it subjects to the opencircuit and the short-circuit faults. So, the paper contribution is the mathematical modeling of the IV characteristic of the PV generator, when it subjects to the open-circuit and the short-circuit faults at the level of its basic components: cells, bypass diodes and blocking diodes. This new methodology employed for modeling the photovoltaic generator is based on known electrical laws as voltages addition in series and in parallel, currents addition in series and in parallel, and finally nodes law.

\section{MODELING THE PHOTOVOLTAIC GENERATOR IN NORMAL FUNCTIONING}

Figure1 presents the photovoltaic generator studied. It consists of five parallel strings. Each one terminates by a blocking diode, for objective to blocking the reversed current in abnormal cases, like shading or in the nights. Also, it contains five modules in series, for objective to increasing the maximum voltage. Each module forms with two groups of cells. Finally, each group contains eighteen cells, regroups by one bypass diode, for objective to blocking the reversed current in the secure path, which designs to protect the generator, in the case of the presence of a fault in any group.

Because, we use in the modeling of the generator cells the one diode model. So, the mathematical modeling of the $\mathrm{I}-\mathrm{V}$ characteristic of the PV generator in its normal functioning is

$$
\left\{\begin{array}{l}
V_{P V_{n f p}}=N_{\text {Cells }} \times N_{\text {Groups }} \times N_{\text {Modules }} \times V_{\text {Cell_imposed }} \\
I_{P V_{n f p}}=N_{\text {Strings }} \times \\
\quad\left(p h i-I_{0} \times\left(e^{\frac{V_{\text {Cell }}+I_{\text {Cell }} \times R_{S}}{a \times D T V}}-1\right)-\frac{V_{\text {Cell }}+I_{\text {Cell }} \times R_{S}}{R_{S H}}\right)
\end{array}\right.
$$




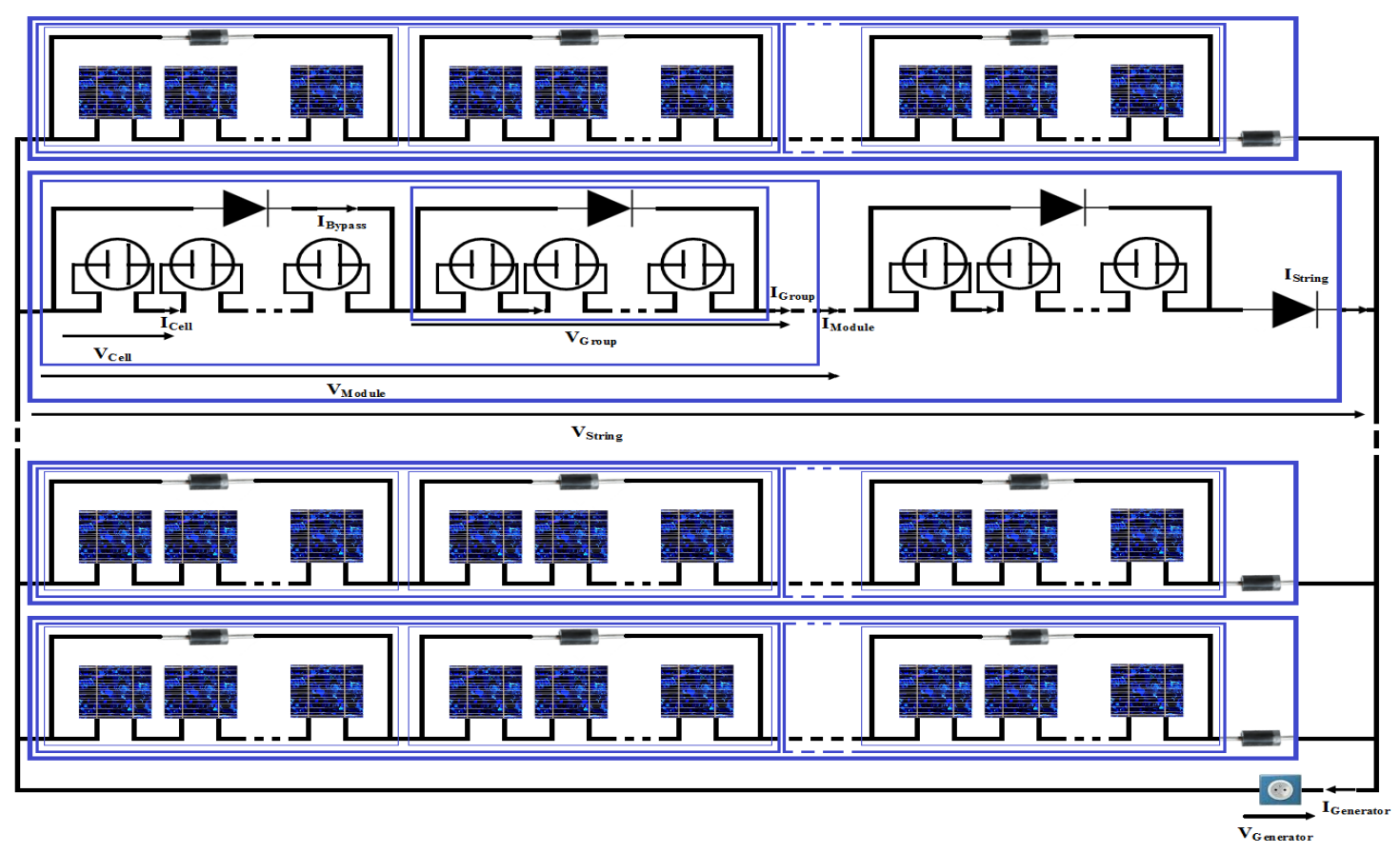

Figure1. Photovoltaic generator described

\section{MODELING THE PHOTOVOLTAIC GENERATOR IN MALFUNCTIONING}

\section{A. Defective Cells}

A link between the two phases of a photovoltaic cell appear a cell short-circuit fault. This latter cancels outright the voltage of the defective cells. It ranks among the most

dangerous defects, because it decreases the faulty generator voltage.

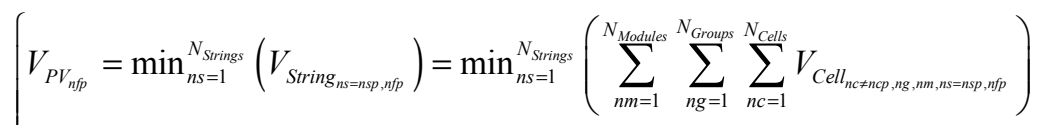

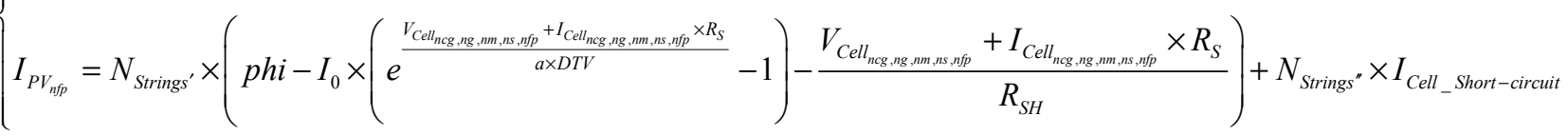

Where: $N_{\text {Strings: }}:$ Number of strings contain at least one good cell. $N_{\text {Strings }} .:$ Number of strings all its cells are defective.

A cell is open-circuit, if its resistance increases up to block its current provided. Practically, a crack at this cell

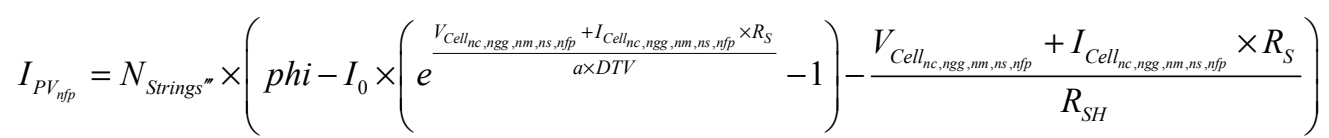

If there is at least one good string in this defective generator

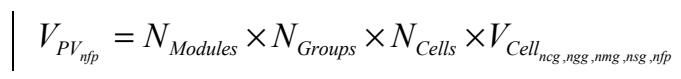

Else

$$
\begin{aligned}
& V_{P V_{\text {nfp }}}=
\end{aligned}
$$

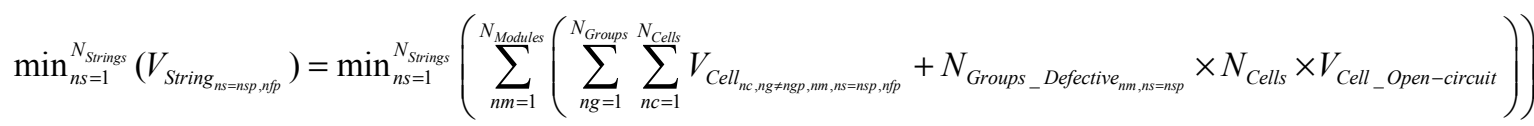

End

Strings, "': Strings contain at least one good group. 


\section{B. Defective Bypass Diodes}

Any connection between the two ports of a bypass diode appears the bypass diode short-circuit fault. This latter increases the group current to its short-circuit value, but it cancels outright its group voltage.

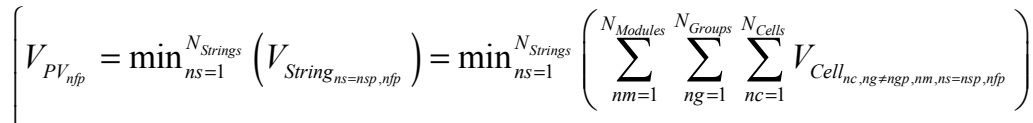

$$
\begin{aligned}
& I_{P V_{n f p}}=
\end{aligned}
$$

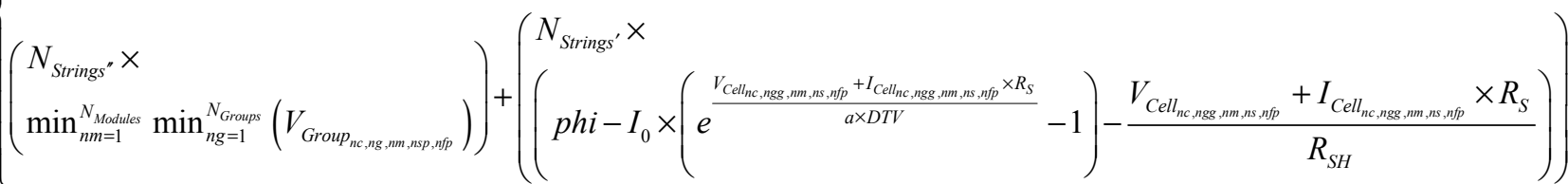

Where:

$\mathrm{N}_{\text {Strings: }}$ : number of strings contains at least one good group. $\mathrm{N}_{\text {Strings, }}$ : number of strings all its groups are defective.

Also, the bypass diode resistance is negligible, when it is busy. But after its uses, its resistance increases up to become an obstacle, which prevents the passage of the current. This problem names in the diagnostic area the bypass diode open-circuit fault.

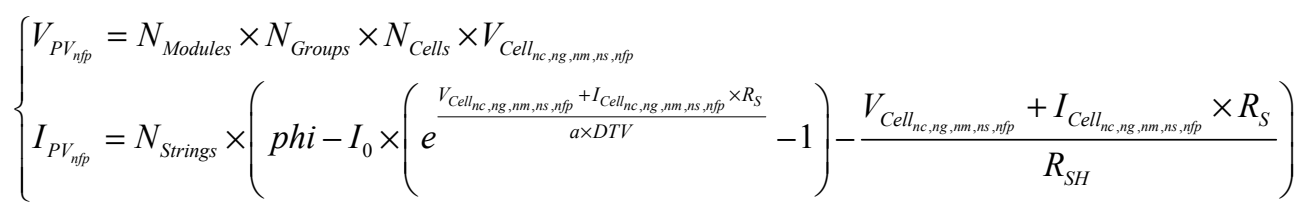

\section{Defective Blocking Diodes}

In the normal functioning of the generator, the presence of the blocking diode short-circuit fault has no influence on its IV characteristic. But, it has a very important role in its abnormal functioning, when its strings have different voltages as in these two cases: 1) if the reversed current and the supplied current of the faulty

strings are not nulls, because these strings become in the open-circuit stat. 2) if the reversed current of the faulty strings is not null and its supplied current is null, because these strings become in receiver stat.

- If the defective strings cells currents are not zero, and its opposite currents are zero

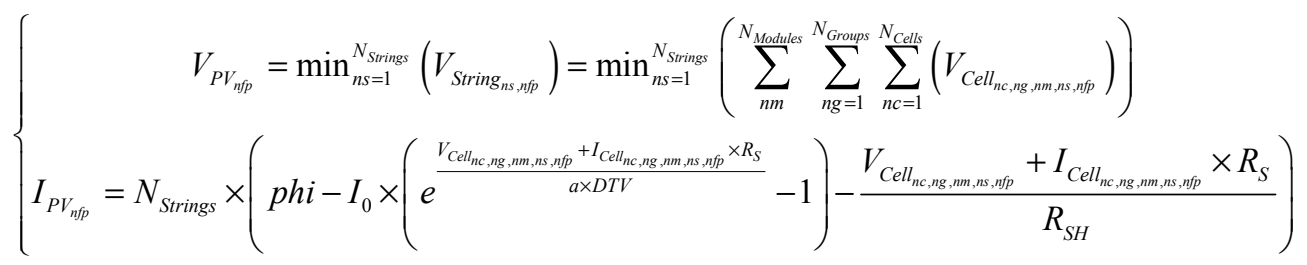

- If the defective strings cells currents are zero and its opposite currents are not zero

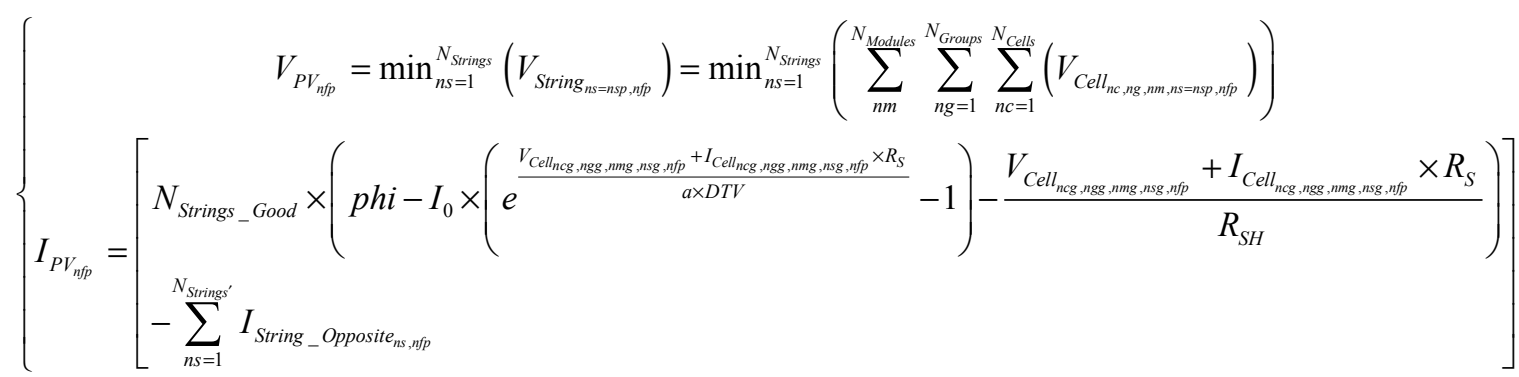

Where $\mathrm{N}_{\text {Strings: }}$ : number of defective strings with provided current null.

- If the defective strings cells currents are not zero, its opposite currents are not zero, and all the generator strings are defective 
$\left\{\begin{array}{l}V_{P V_{n f p}}=N_{\text {Modules }} \times N_{\text {Groups }} \times N_{\text {Cells }} \times V_{\text {Cell_open-circuit }} \\ I_{P V_{n f p}}=0\end{array}\right.$

But, if this faulty generator contains at least one good string

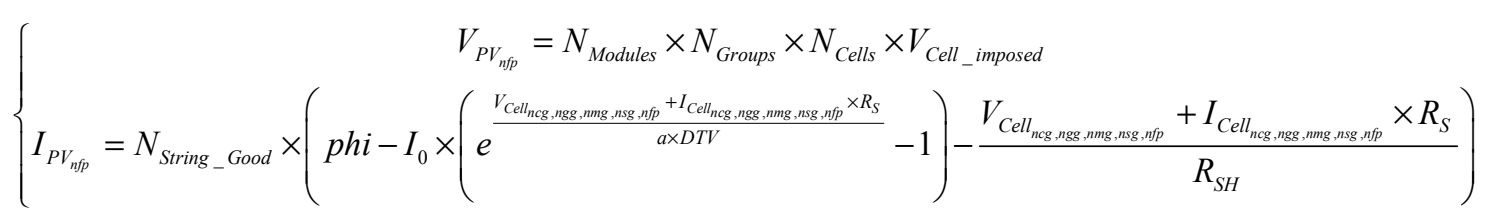

Increasing the temperature, the existence of a shortcircuit and the presence of cracks appear the blocking

If all the generator strings are defective

$\left\{\begin{array}{l}I_{P V_{n f p}}=0 \\ V_{P V_{n f p}}=N_{\text {Modules }} \times N_{\text {Groups }} \times N_{\text {Cells }} \times V_{\text {Cell_Open-circuit }}\end{array}\right.$

diode open-circuit fault. Its existence can block the flow of the current in the faulty strings.

Else

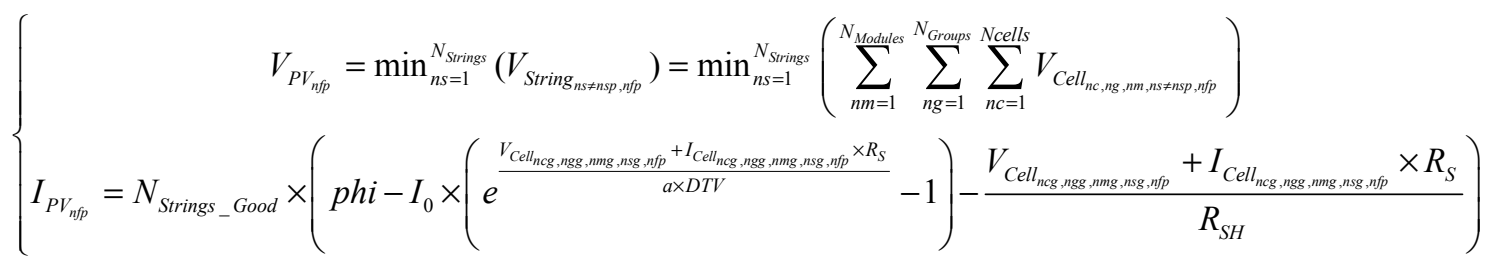

End

\section{Simulation results}

The results simulations of the PV generator model are shown in the following Figs. 2 to 8.

1) Figure 2 shows the IV characteristic and the power of a good photovoltaic generator.

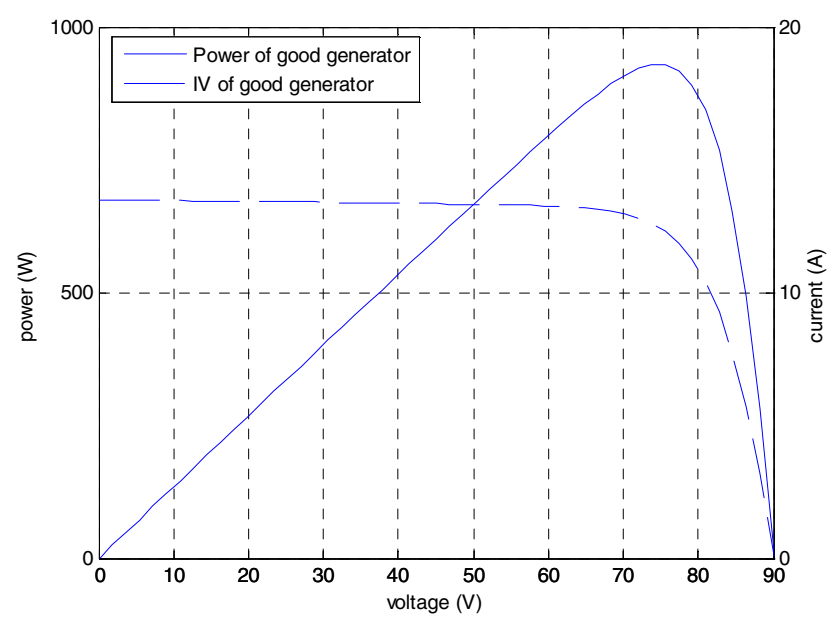

Figure2. I-V characteristic and power of a good PV generator

2) Figure3 presents the functioning of the generator containing cells short-circuit. It shows that the power of a PV generator decreases proportional to the number of the defective cells.

3) Figure4 presents the functioning of the generator containing bypass diodes short-circuit. It shows that the power of a PV generator decreases proportional to the number of the defective diodes. Because, this fault can affects the group voltage. But, the current remains independent unless all its string groups are defective.

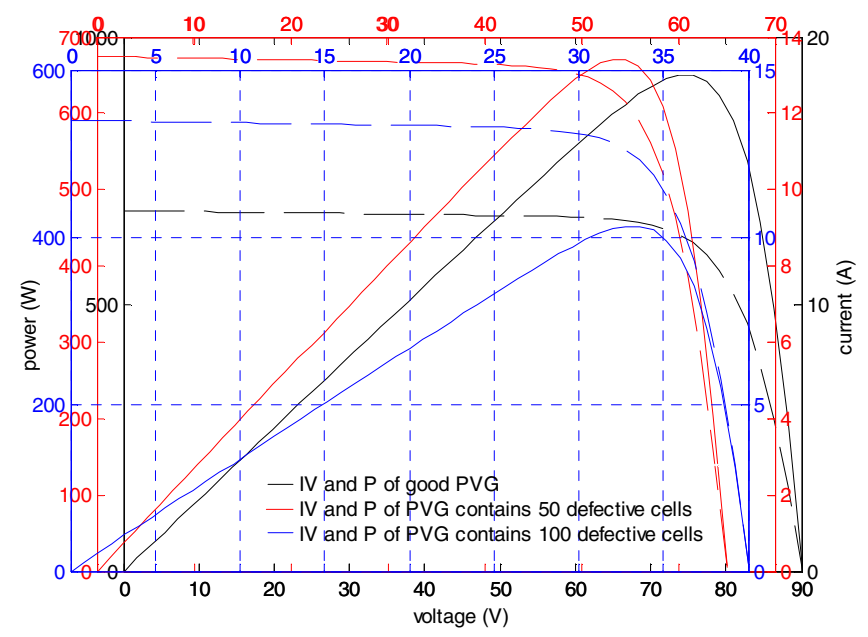

Figure3. $I V \& P$ of the PV contains cells short-circuit.

4) Figure 5 presents the functioning of the generator containing blocking diodes short-circuit. It shows that this defect makes a significant deterioration of the generator power. Because, it creates the reversed current in the absence of the cells supplied current in the faulty string, and this latter becomes in the receiver stat. Otherwise, it becomes in the open-circuit stat. 


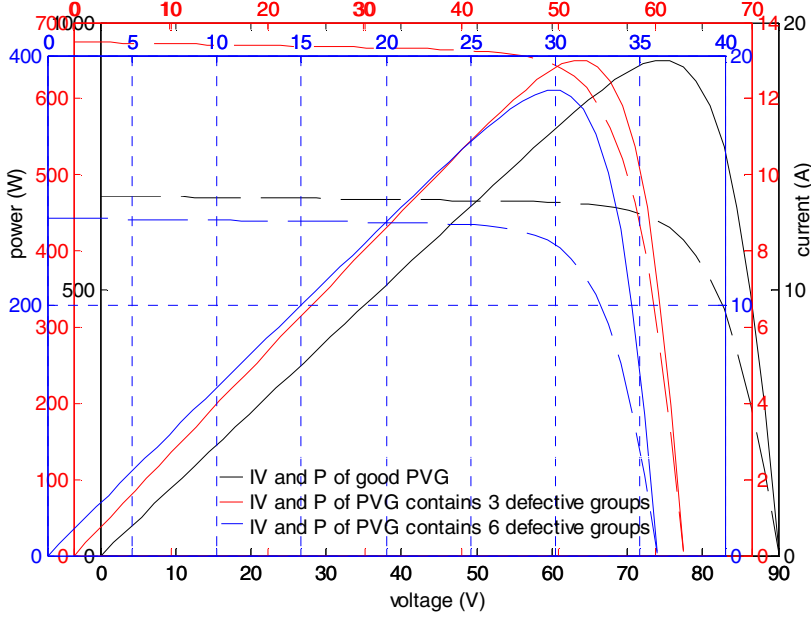

Figure4. $I V \& P$ of the PV contains bypass diodes short-circuit

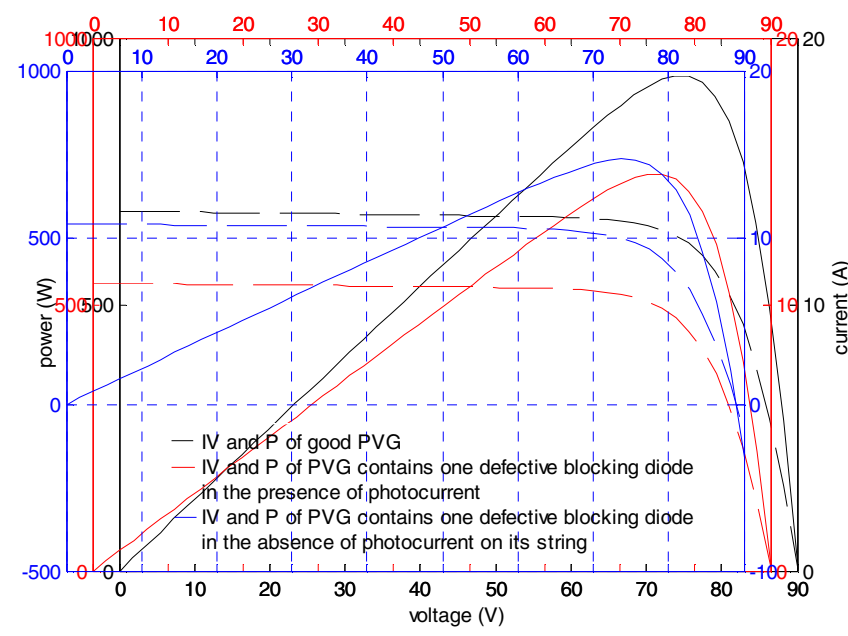

Figure5. IV \& $P$ of the PV contains blockings diodes short-circuit

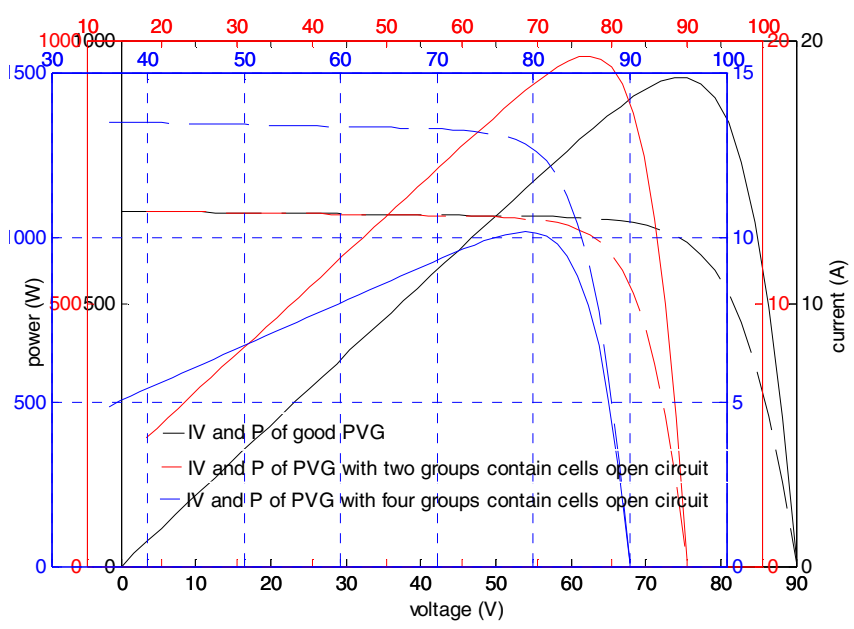

Figure6. IV \& $P$ of the PV contains cells open-circuit.

5) Figure6 presents the functioning of the generator containing cells open-circuit. It shows that this fault has no influence on the generator current, except in the failure of all the groups within one of its strings. It increases the generator voltage, if all its strings are failing, and it increases proportionally with the number of its faulty groups, till it reaches its open-circuit value.

6) Figure7 presents the functioning of the generator containing bypass diodes open-circuit. It shows that this fault classifies among the major flaws, because its detection is difficult and requires others parameters, such as the sunlight. So, it has no influence on the characterization of the generator, as long as the group assembled by this defective diode is in the normal functioning.

7) Figure 8 presents the influence of the blocking diode open-circuit on the functioning of the PV generator. It shows that this defect can cut the current flowing across the faulty string, and therefore increases its voltage to the maximum. It has no influence on the generator voltage, which contains at least one good string. But, its current is inversely proportional to the number of blocking diode open-circuit.

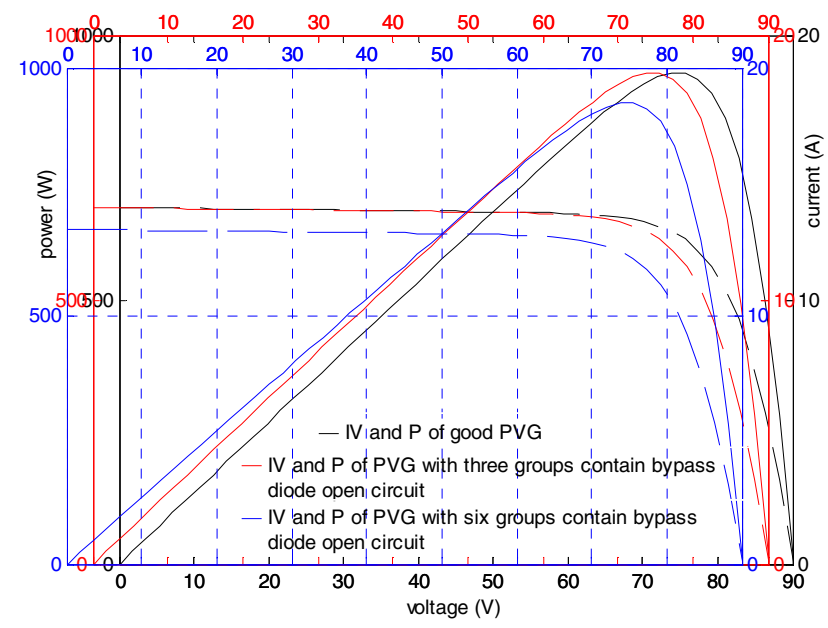

Figure7. $I V \& P$ of the PV contains bypass diode open-circuit.

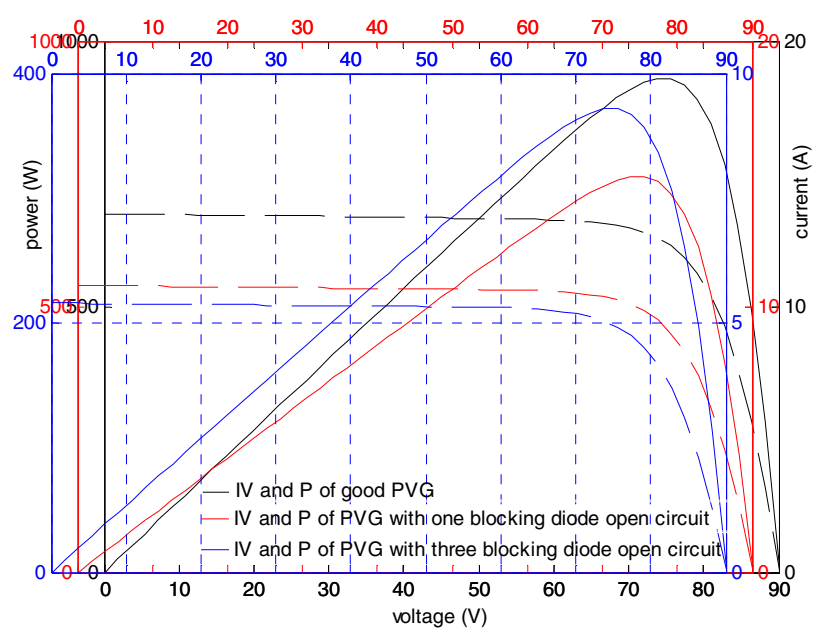

Figure8. IV \& $P$ of the PV contains blocking diode open circuit. 


\section{CONCLUSION}

In this paper, we proposed a new methodology for the mathematical modeling of the PV generator operation, when its basic components are subjected to one of these defects: short-circuit and open-circuit.

This new methodology result a rich database contained six class types of the faulty PV generator operation. This database can use for the prognosis and the diagnosis of the open-circuit and the short-circuit defects particularly.

The future work is to propose a hybrid model shows the generator operation, when it contains the six types of the faults at the same time, which is closest to the reality.

\section{REFERENCES}

[1]. W. Rezgui, L.H. Mouss, M.D Mouss, «Modeling of a photovoltaic field in malfunctioning ", in Proceedings of the 2013 IEEE CODIT (International Conference on Control, Decision and Information Technologies), Hammamet (Tunisia), pp. 788 - 793, 6-8 May 2013.

[2]. W. Rezgui, L.H. Mouss, N.K. Mouss, M.D. Mouss, Y. Amirat and M.E.H. Benbouzid, «Electrical faults modeling of the photovoltaic generator", IREMOS (International Review on Modelling and Simulations), Vol.7, N², May 2014.

[3]. L. Dorobantu, M.O. Popescu, C.L. Popescu, «Yield loss of photovoltaic panels caused by depositions », in the proceeding of 2011 IEEE ATEE ( $7^{\text {th }}$ International Symposium on Advanced Topics in Electrical Engineering), pp. 1 - 4, Bucharest , 12-14 May 2011.

[4]. F. Bizzarri, A. Brambilla, G. Gruosso, C. Guardiani, A.S Vincentelli, G.S. Gajani, "Modeling and estimating yield and efficiency of photovoltaic solar parks », in the proceeding of 2013 IEEE ICIT (International Conference on Industrial Technology), pp. 734 - 739, Cape Town, 25-28 Feb. 2013.

[5]. K. Ardani, G. Barbose, R. Margolis, D. Feldman, « Quantifying non-hardware balance of system costs for photovoltaic installations in the United States using a combined annual expenditure-labor hour productivity approach », in the proceeding of 2012 IEEE PVSC ( $38^{\text {th }}$ Photovoltaic Specialists Conference), pp. 001762 - 001767, Austin, TX, 3-8 June 2012.

[6]. M. Behnke, A. Ellis, «Contribution of photovoltaic power generation systems to AC short circuits - A survey of current modeling practices and challenges », in Proceedings of the 2013 IEEE PVSC (Photovoltaic Specialists Conference), pp. 3128 3133, Tampa, FL, 16-21 June 2013.

[7]. S. Hadji, J.-P. Gaubert, F. Krim, « Maximum Power Point Tracking (MPPT) for Photovoltaic systems using open circuit voltage and short circuit current ", in Proceedings of the 2013
IEEE ICSC $\left(3^{\text {rd }}\right.$ International Conference on Systems and Control), pp. $87-92$, Algiers, 29-31 Oct. 2013.

[8]. W. Xiao, F.F. Edwin, G. Spagnuolo, J. Jatskevich, «Efficient Approaches for Modeling and Simulating Photovoltaic Power Systems », IEEE Journal of Photovoltaics , Vol. 3, Issue. 1, pp. 500 - 508, Jan. 2013.

[9]. Y. Mahmoud, W. Xiao, H.H. Zeineldin, « A Simple Approach to Modeling and Simulation of Photovoltaic Modules », IEEE Transactions on Sustainable Energy, Vol. 3, Issue. 1, pp. 185 186, Jan. 2012

[10]. K. Touafek, M. Haddadi, A. Malek, « Modeling and Experimental Validation of a New Hybrid Photovoltaic Thermal Collector », IEEE Transactions on Energy Conversion, Vol. 26, Issue: 1, pp. 176 - 183, March 2011

[11]. S. Eidelloth, F. Haase, R. Brendel, «Simulation Tool for Equivalent Circuit Modeling of Photovoltaic Devices », IEEE Journal of Photovoltaics, Vol. 2, Issue. 4, pp. 572 - 579, Oct. 2012.

[12]. F. Adamo, F. Attivissimo, A.D. Nisio, M. Spadavecchia, «Characterization and Testing of a Tool for Photovoltaic Panel Modeling ", IEEE Transactions on Instrumentation and Measurement, Vol. 60, Issue. 5, pp. 1613 - 1622, May 2011

[13]. P.P. Dash, M. Kazerani, « Dynamic Modeling and Performance Analysis of a Grid-Connected Current-Source Inverter-Based Photovoltaic System », IEEE Transactions on Sustainable Energy, Vol. 2, Issue. 4, pp. $443-450$, Oct. 2011

[14]. L. Cristaldi, M. Faifer, M. Rossi, F. Ponci, «A Simple Photovoltaic Panel Model: Characterization Procedure and Evaluation of the Role of Environmental Measurements », IEEE Transactions on Instrumentation and Measurement, Vol. 61, Issue. 10, pp. $2632-2641$, Oct. 2012.

[15]. A. Chatterjee, A. Keyhani, D. Kapoor, «Identification of Photovoltaic Source Models ", IEEE Transactions on Energy Conversion, Vol. 26, Issue. 3, pp. 883 - 889, Sept. 2011.

[16]. M. Hejri, H. Mokhtari, M.R. Azizian, M. Ghandhari, L. Soder, « On the Parameter Extraction of a Five-Parameter Double-Diode Model of Photovoltaic Cells and Modules », IEEE Journal of Photovoltaics, Vol. 4, Issue. 3, pp. 915 - 923, May 2014.

[17]. W. Rezgui, L. H. Mouss, M. D. Mouss, O. KADRI and A. DISSA, «Electrical faults detection for the intelligent diagnosis of a photovoltaic generator », Journal of Electrical Engineering, Vol. 14, Issue. 1, pp. 77-84, March 2014.

[18]. W. Rezgui, L.H. Mouss, N.K. Mouss, M.D. Mouss and M.E.H Benbouzid, «A smart algorithm for the diagnosis of short-circuit faults in a photovoltaic generator », in Proceedings of the 2014 IEEE ICGE, Sfax (Tunisia), pp. 1-5, March 2014.

[19]. W. Rezgui, L.H. Mouss, N.K. Mouss, M.D. Mouss and M.E.H. Benbouzid, « A Regression Algorithm for the Smart Prognosis of a Reversed Polarity Fault in a Photovoltaic Generator ", in Proceedings of the 2014 IEEE ICGE, Sfax (Tunisia), pp. 1-5, March 2014. 